\title{
Long-chain fatty acid effects on peroxisome proliferator-activated receptor- $\alpha-$-regulated genes in Madin-Darby bovine kidney cells: Optimization of culture conditions using palmitate
}

\author{
B. J. Thering, M. Bionaz, and J. J. Loor ${ }^{1}$ \\ Mammalian NutriPhysioGenomics, Department of Animal Sciences and Division of Nutritional Sciences, University of Illinois, Urbana 61801
}

\begin{abstract}
Studying long-chain fatty acid (LCFA) effects on gene network expression in bovine cells could provide useful information for future practical applications. An optimized in vitro system that does not require tissue collection or cell isolation could fill a niche in the study of PPAR $\alpha$ activity in ruminants. Specific aims were to optimize culture conditions in Madin-Darby bovine kidney (MDBK) cells to achieve maximal mRNA expression of known peroxisome proliferator-activated receptor- $\alpha$ (PPAR $\alpha)$ target genes using palmitate (16:0) as a representative LCFA. Variables included length of incubation time, use of albumin-bound (4:1 molar proportion) 16:0 (A16:0), or addition of insulin. A first time-course experiment tested culturing cells in Dulbecco's modified Eagle's medium with $150 \mu M$ PPAR ligand $\mathrm{Wy}-14643$ (WY) and A16:0. A second experiment tested the effects of albumin and insulin using 150 $\mu M$ of 16:0 without albumin or insulin (-Alb/-Ins), 16:0 without albumin plus $5 \mathrm{mg} / \mathrm{L}$ of bovine insulin (-Alb/+Ins), A16:0 without insulin (+Alb/-Ins), or a control. A third experiment was a preliminary metabolic characterization of cells and assessed intracellular lipid droplet formation after treatment with $150 \mu M$ of 16:0 or an ethanol control. For all experiments, cells were harvested at $0,6,12,18$, and $24 \mathrm{~h}$ posttreatment. In experiments 1 and 2, mRNA expression was assessed by quantitative PCR of selected PPAR $\alpha$ target genes as well as PPAR $\alpha$ coactivators (ACOX1, CPT1A, ACADVL, ACSL1, PPARA, PPARGC1A, $L P I N 1)$. In experiment 1 , there was a linear increase in mRNA expression of CPT1A ( 500\%) and ACSL1 (50 to $200 \%$ ) by $6 \mathrm{~h}$ of incubation with both WY and A16:0. The LPIN1 mRNA increased by $>100 \%$ by $6 \mathrm{~h}$ only with A16:0. Further, there was a linear increase in expression of PPARA ( 100\%) with A16:0 through $24 \mathrm{~h}$ of incubation. In experiment 2, insulin increased, and coupling LCFA with albumin tended to delay the
\end{abstract}

Received September 25, 2008.

Accepted December 23, 2008.

${ }^{1}$ Corresponding author: jloor@illinois.edu response in expression of $C P T 1 A$ and ACSL1 to 16:0. Data indicated a toxic effect of $150 \mu M$ free 16:0 as assessed by cell counts after $12 \mathrm{~h}$ of incubation. In experiment 3, MDBK cells appeared to use glucose and AA as energy sources and were able to secrete triglycerides. In addition, MDBK cells cultured with $150 \mu M$ of 16:0 had a substantial uptake of LCFA and synthesized intracellular lipid droplets. Overall, results indicated that a 6-h incubation with free LCFA and addition of insulin was suitable to detect marked effects on mRNA expression of PPAR $\alpha$ target genes in MDBK cells.

Key words: Madin-Darby bovine kidney cell, peroxisome proliferator-activated receptor, fatty acid, gene expression

\section{INTRODUCTION}

In rodents, long-chain fatty acids (LCFA) are potent in eliciting greater peroxisomal and mitochondrial $\beta$-oxidation of fatty acids (Kumamoto and Ide, 1998), lower esterification of fatty acids (Malewiak et al., 1988), and altered profiles and clearance of plasma lipoproteins (Lambert et al., 1998) through direct binding to peroxisome proliferator-activated receptor (PPAR)- $\alpha$ (Jump, 2002). Gene transcription exerts long-term regulation of metabolism (Desvergne et al., 2006) and, as such, represents an important biological control point. In bovine, few experiments have assessed the effects of LCFA on transcription regulation via PPAR. Because of renewed interest in the use of dietary lipids as management tools to prevent periparturient metabolic and reproductive disorders (Andersen et al., 2008; Santos et al., 2008), these types of studies can provide much-needed data that might be of practical application in the future.

Previous studies dealing with LCFA effects on ruminant metabolism have used isolated liver cells from preruminant calves (Mashek and Grummer, 2003, 2004), but the isolation procedure is tedious and the short life span of the cells is a limiting factor. Thus, identification of suitable cell culture systems responsive to PPAR activation in ruminants can circumvent the need for liver tissue or hepatocytes. Madin-Darby bovine kid- 
ney (MDBK) cells are responsive to PPAR agonists and LCFA (Bionaz et al., 2008a). Using a 13,000 gene bovine oligonucleotide microarray (Loor et al., 2007), we recently characterized the transcriptome of these cells relative to periparturient cow liver tissue (http:// labs.ansci.uiuc.edu/loor/projects_MDBK.html; Bionaz et al., 2008b), which is typically flooded with LCFA because of extensive adipose lipolysis (Drackley, 1999). We observed that the expression of several transcription factors (e.g., PPAR $\alpha$, PPAR $\gamma$ ) in this cell line was strikingly similar to those in bovine liver. Both tissue and MDBK cells also had similar mRNA abundance of genes involved in basic metabolic processes (e.g., synthesis of lipid, protein synthesis) and response to hormones. Liver tissue had greater expression of genes involved in LCFA oxidation and other typical liver functions around parturition (e.g., acute-phase reaction, urea metabolism). In contrast, MDBK cells had greater mRNA abundance of genes involved in cell growth and proliferation. Despite those expected differences, the large degree of similarity that was uncovered suggested that MDBK cells might be a suitable model for studies of LCFA effects on activation of transcription factors and nuclear receptors. Compared with primary bovine hepatocyte cultures, MDBK cells are much easier to maintain and manipulate in culture. Although the MDBK system cannot supplant in vivo techniques or bovine hepatocyte cultures, it could fill a niche in the study of PPAR $\alpha$ metabolism in ruminants.

Culture conditions for MDBK cells have not been thoroughly evaluated. In a previous study (Bionaz et al., 2008a), it was shown that incubation of palmitate (16:0) at 100 and $200 \mu M$ compared with a control resulted in greater mRNA expression of carnitine

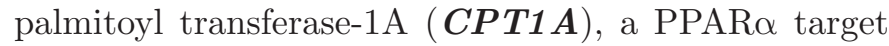
gene. The higher dose, however, had a toxic effect on cells. Despite that initial effort, several limitations must be overcome before the MDBK system can have wider use in metabolic studies. For instance, conclusions were based on the evaluation of a single PPAR $\alpha$ target gene. In addition, MDBK cells were cultured in medium devoid of insulin, which might be essential for cellular metabolism (Donkin and Armentano, 1993) and PPAR $\alpha$ activity (Schoonjans et al., 1997). Further, the MDBK cells used were at a passage $>230$. Previous evidence has indicated that metabolic capacity is diminished as the number of passages in cultured cells increases (Rubin, 1997).

The objectives of the present experiments were to optimize MDBK culture conditions to achieve maximal mRNA expression of known PPAR $\alpha$ target genes by using 16:0 as a representative LCFA. In addition, we performed a preliminary metabolic characterization of cells through temporal measurement of metabolite con- centrations in surfactant media as well as intracellular lipid droplet accumulation.

\section{MATERIALS AND METHODS}

\section{Cell Culture}

Cells were obtained from the American Type Culture Collection (CCL-22, ATCC, Manassas, VA) at passage 110. They were propagated in sterile $75-\mathrm{cm}^{2}$ cantedneck, vented flasks (430641, Corning, Glendale, AZ) in complete medium (Dulbecco's Modified Eagle's Medium/High Glucose with L-Glutamine/Without Sodium Pyruvate, no. sh3002202, Hyclone, Logan, UT) supplemented with $10 \%$ fetal bovine serum (no. 10438026, Gibco, Invitrogen, Carlsbad, CA) and 1\% HyQ Antibiotic/Antimycotic Solution 100× (no. SV30079.01, HyClone) at $37^{\circ} \mathrm{C}$ in $5 \% \mathrm{CO}_{2}$ in air. Medium was changed every $2 \mathrm{~d}$ and cells were subcultured at 70 to $80 \%$ confluence by rinsing once with $10 \mathrm{~mL}$ of PBS buffer without $\mathrm{Ca}$ and $\mathrm{Mg}$ (no. sh3002802, HyClone), addition of $3 \mathrm{~mL}$ of $0.25 \%$ trypsin (no. sh3004201, Hyclone) plus $3 \mathrm{~mL}$ of Cellstripper (no. 25-056-Cl, Mediatech Inc., Manassas, VA), and incubated at $37^{\circ} \mathrm{C}$ for 5 to $10 \mathrm{~min}$ (i.e., until evidence of cell detachment). Trypsin activity was inhibited by addition of $6 \mathrm{~mL}$ of fresh medium at $37^{\circ} \mathrm{C}$.

\section{Experiment 1}

At passage 112, cells were plated in 6-well plates (no. 3516, Corning, Glendale, AZ) in complete medium and incubated overnight at $37^{\circ} \mathrm{C}$. Treatments were applied when cells reached approximately $90 \%$ confluence. Cells were subsequently cultured for $24 \mathrm{~h}$ in fresh complete medium containing the treatments of interest. On the basis of previous data (Bionaz et al., 2008a), we elected to use $150 \mu M$ of 16:0 (N-16-A, Nu-Chek Prep Inc., Elysian, MN) as a compromise between maximum activation of transcription and absence of toxic effects. The specific PPAR $\alpha$ ligand Wy-14643 (WY; 270-198-M010, Alexis Biochemicals, Lausen, Switzerland) was used at the same dose to enable a direct comparison of potency. It should be noted that in addition to activating PPAR $\alpha$, WY could potentially activate PPAR $\gamma$ to some degree (Lehmann et al., 1997). The WY was dissolved in 100\% ethanol; thus, $5 \mathrm{~mL} / \mathrm{L}$ of $100 \%$ ethanol was used as a control. Palmitate was coupled with albumin (4:1) after saponification with an equimolar amount of $\mathrm{NaOH}$ and suspended in absolute ethanol (95\% in water); thus, a solution of $\mathrm{NaOH}$ plus albumin in ethanol without 16:0 was used as a control for this treatment. Treatments were run in duplicate and final data were obtained after correcting by the 
specific control. Cells were harvested at 0 (in duplicate; cells without any treatment), 3, 6, 12, 18, and $24 \mathrm{~h}$ posttreatment. Cells were harvested with $1 \mathrm{~mL}$ of TRIzol reagent (Invitrogen) and frozen at $-80^{\circ} \mathrm{C}$. A single well for time 0 (before treatments) and at $18 \mathrm{~h}$ for the 16:0 and WY treatments was harvested with $0.8 \mathrm{~mL}$ of $0.25 \%$ trypsin as reported above and resuspended in 1 $\mathrm{mL}$ of fresh basal medium after centrifugation for cell counting and viability assessment. Cells were counted under a microscope using a Bürker counting chamber with addition of Trypan blue solution.

\section{Experiment 2}

In experiment 1 , culture medium was devoid of hormones besides those that might have been components of the fetal bovine serum. The aim of experiment 2 was to test the effect of addition of insulin to culture medium and to compare the effect of coupling 16:0 with albumin (4:1 molar proportion) vs. the use of uncoupled 16:0. For this experiment, we used albumin-16:0 as in experiment 1 . The treatment without albumin was from a stock of 16:0 prepared by saponification with equimolar amounts of $\mathrm{NaOH}$ and suspended in ethanol. Bovine insulin (no. I6634, Sigma) was used at a dose of $5 \mathrm{mg} / \mathrm{L}$. The experimental design included cultures of 16:0 without albumin and insulin (-Alb/-Ins), 16:0 without albumin plus insulin (-Alb/+Ins), 16:0 with albumin without insulin (+Alb/-Ins), and control (5 $\mathrm{mL} / \mathrm{L}$ of $95 \%$ ethanol in water plus $\mathrm{NaOH}$ ). A treatment with both albumin and insulin was not included because we were specifically interested in individual effects of albumin and insulin. The MDBK cells at passage 112 were cultured and harvested using the same procedures as in experiment 1 . All treatments had a concentration of $150 \mu M 16: 0$ and were run in duplicate in 6 -well culture plates.

\section{Experiment 3}

A time-course experiment was run in 6-well plates for $24 \mathrm{~h}$ in duplicate. Two wells per treatment were cultured for Oil-O-Red and surfactant medium analysis, and an additional 2 wells per treatment were cultured for cell counting. Treatments were $150 \mu M$ 16:0 saponified in $95 \%$ ethanol and a control $(5 \mathrm{~mL} / \mathrm{L}$ of $95 \%$ ethanol in water). Treatments were applied with cells at approximately 70 to $80 \%$ confluence. Cells were cultured in $2 \mathrm{~mL}$ of HyQ Minimum Essential Media/ Earle's Balanced Salts (MEM/EBSS, no. SH30024.02, HyClone) with $10 \%$ fetal bovine serum and containing bovine insulin $(5 \mathrm{mg} / \mathrm{L})$. The use of essential medium was for the purpose of starving cells so that potentially greater uptake of LCFA could be achieved. Aliquots of medium were stored in $1.5-\mathrm{mL}$ sterile microfuge tubes (no. 05-408-138, Fisher Scientific, Pittsburgh, PA) at $0,3,6,12$, and $24 \mathrm{~h}$ posttreatment and preserved at $-20^{\circ} \mathrm{C}$. The remaining medium was removed and OilO-Red staining (no. 0-0625, Sigma) was added to evaluate intracellular triglyceride (TG) droplet formation. Media samples were analyzed for urea, total protein, glucose, NEFA, and TG at the Veterinary Diagnostics Laboratory, University of Illinois. Oil-O-Red staining was applied to cells after fixation with $10 \%$ formalin following a wash with PBS. Fixation was performed for 30 to $60 \mathrm{~min}$. Fixed cells were washed gently with water, $2 \mathrm{~mL}$ of $60 \%$ isopropanol was added to cover the bottom of each well, and the mixture was let stand for $5 \mathrm{~min}$. Isopropanol was removed and $1 \mathrm{~mL}$ of a filtered working solution of Oil-O-Red staining (300 $\mathrm{mg} / 100 \mathrm{~mL}$ of $99 \%$ isopropanol) was added. Cells were incubated for $5 \mathrm{~min}$, Oil-O-Red staining was removed, and cells were rinsed with tap water. One milliliter of hematoxylin (HHS-16, Sigma) to stain the nucleus was added for $1 \mathrm{~min}$, and cells were rinsed carefully with tap water. Pictures were taken using an inverted microscope at $400 \times$ magnification; images are accessible in the supplemental online-only material (http://jds.fass. org/content/vol92/issue5).

To verify potential effects of $150 \mu M$ free 16:0 (i.e., not bound to albumin) on cell proliferation, we used a Coulter Particulate Counter (Beckman Coulter, Fullerton, CA) to estimate the number of cells per well. Cells were collected using $0.25 \%$ trypsin as described for cell cultures. After collection, cells were resuspended in 1 $\mathrm{mL}$ of fresh medium at $37^{\circ} \mathrm{C}$ before counting. Viability of these cells was assessed with Trypan blue.

\section{Quantitative PCR}

Ribonucleic acid extraction, quality assessment, quantitative PCR, cDNA synthesis, and the design and evaluation of primers have been described in detail previously (Bionaz and Loor, 2008). We tested the activation of PPAR $\alpha$ by measuring 8 genes (Table 1), 4 of them known to be PPAR $\alpha$ downstream targets in nonruminants (Mandard et al., 2004): CPT1A, acyl-coenzyme A oxidase 1 ( $\boldsymbol{A} \boldsymbol{C O X} \mathbf{1})$, acyl-coenzyme A dehydrogenase very long chain $(\boldsymbol{A C A D V L})$, and acyl-coenzyme A synthetase long-chain family member 1 (ACSL1). In addition to PPAR $\alpha(\boldsymbol{P P A R A})$, we evaluated expression of 2 known genes associated with PPAR $\alpha$ activation: peroxisome proliferative-activated

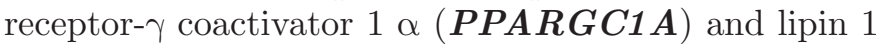
(LPIN1). Messenger RNA expression of the transcription factor sterol regulatory element-binding factor 1 ( SREBF1) also was assessed because of its central role in lipid synthesis (Desvergne et al., 2006). Data 
Table 1. GenBank accession number, hybridization position, sequence, and amplicon size of primers used ${ }^{1}$

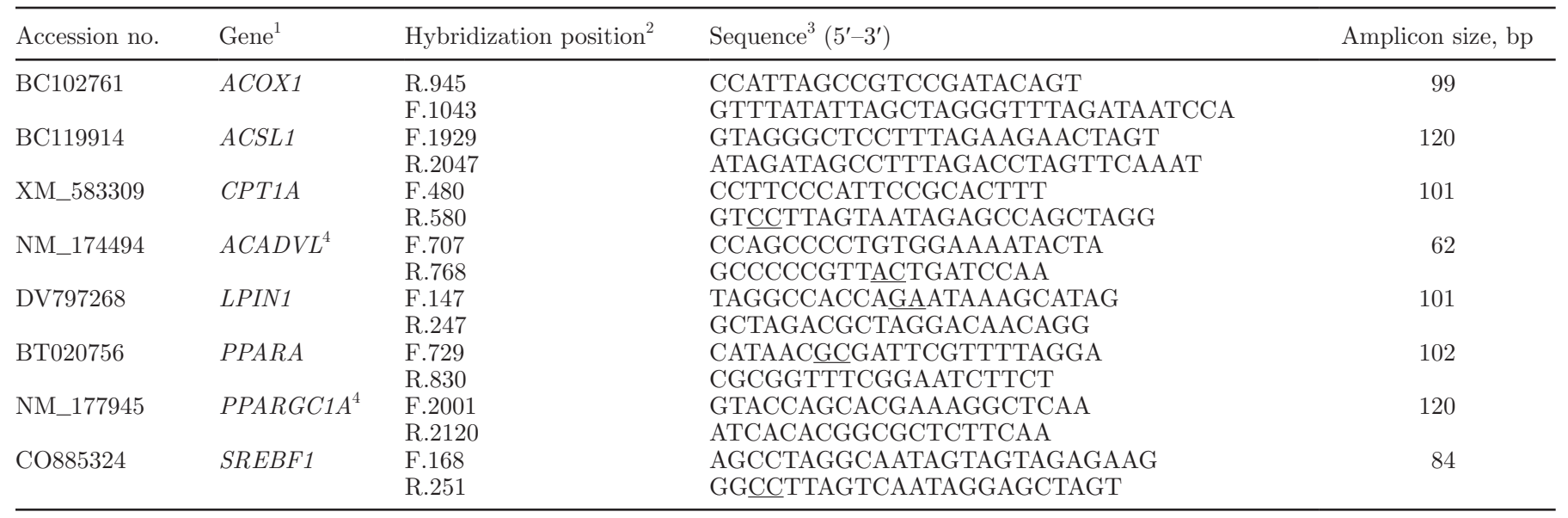

${ }^{1} A C O X 1=$ acyl-CoA oxidase $1 ; A C S L 1=$ acyl-coenzyme A synthetase long-chain family member $1 ; C P T 1 A=$ carnitine palmitoyl transferase$1 \mathrm{~A} ; A C A D V L=$ acyl-coenzyme A dehydrogenase very long chain; $L P I N 1=$ lipin $1 ; P P A R A=$ peroxisome proliferator-activated receptor- $\alpha$; $P P A R G C 1 A=$ peroxisome proliferative-activated receptor- $\gamma$ coactivator $1 \alpha ; S R E B F 1=$ sterol regulatory element-binding factor 1 .

${ }^{2}$ Primer direction $(\mathrm{F}=$ forward; $\mathrm{R}=$ reverse) and hybridization position on the sequence.

${ }^{3}$ Exon-exon junctions are underlined.

${ }^{4} A C A D V L$ was reported previously (Loor et al., 2005), as was PPARGC1A (Harvatine and Bauman, 2006).

were analyzed with the 7900 HT Sequence Detection Systems software (version 2.2.1, Sequence Detection Systems, Applied Biosystems, Foster City, CA). The final data were normalized using $R P S 9$, which was the most stable gene among 6 tested (MTG1, PPP1R11, MRPL39, RPS15A, RPS9, and UXT; unpublished data. Description and primer pair information for these genes are available online at http//labs.ansci.uiuc.edu/ loor/qPCR_Primer_Tables.html). Internal control gene stability analysis was performed as described previously (Bionaz and Loor, 2007; Piantoni et al., 2008).

\section{Statistical Analysis}

A MIXED model with repeated measures was used (release 8.0; SAS Inst. Inc., Cary, NC). After evaluation of several covariance structures via Akaike's information criterion and -2 restricted log-likelihood, the best fit (i.e., lower Akaike's information criterion) was obtained using autoregressive order 1 . In experiments 1 and 3 , the model included the fixed effects of time $(0$, $3,6,12$, and $24 \mathrm{~h}$ ), treatment (WY, 16:0), and the time $\times$ treatment interaction. In experiment 2 , the model included the fixed effects of time $(0,3,6,12$, and 24 $\mathrm{h})$, treatment (16:0, albumin, insulin), and all potential interactions. Replicate was considered a random effect. Statistical significance was declared at $P \leq 0.05$.

\section{RESULTS AND DISCUSSION}

There were $1.6 \times 10^{6}$ cells/well with $>99 \%$ viability at time 0 (data not shown). In experiment 1 at $18 \mathrm{~h}$,
WY and 16:0 resulted in similar numbers of cells $(3.15$ $\times 10^{6}$ and $3.14 \times 10^{6}$ ) with $>99 \%$ viability. Thus, cells cultured as reported above had a 3-fold increase in number by $18 \mathrm{~h}$, and there was no difference between treatments in both viability and cell proliferation. Most important, $150 \mu M$ of 16:0 bound 4:1 with albumin had no detrimental effects on cell viability.

\section{Temporal PPARa Activation}

In experiment 1 , putative PPAR $\alpha$ target genes, except $A C O X 1$, increased mRNA expression over time with WY (Figure 1). The lack of response of ACOX1 to PPAR $\alpha$ activation confirms previous findings (Bionaz et al., 2008a). In a similar fashion, the pattern of CPT1A over time confirms the responsiveness of MDBK cells to the PPAR $\alpha$ agonist WY (Bionaz et al., 2008a). However, the MDBK cells in the present study responded to a larger extent when challenged with WY compared with the previous study (Bionaz et al., 2008a), potentially because they were used at fewer passages (i.e., 113 vs. $>230$ ). In that previous experiment, CPT1A increased in response to WY by $<100 \%$ at $18 \mathrm{~h}$ and approximately $150 \%$ at $24 \mathrm{~h}$ posttreatment, whereas in the present experiment, the increase tended to be significant by $6 \mathrm{~h}(270 \% ; P=$ 0.07 ) and reached an increase of $>500 \%$ by $18 \mathrm{~h}$. The $A C A D V L$ had a delayed response, with an increase of approximately $70 \%$ by $18 \mathrm{~h}$. The difference in response observed in the present study compared with that by Bionaz et al. (2008a) can partly be related to the lower dose of WY (50 vs. $150 \mu M$ ) used in the previous study. 

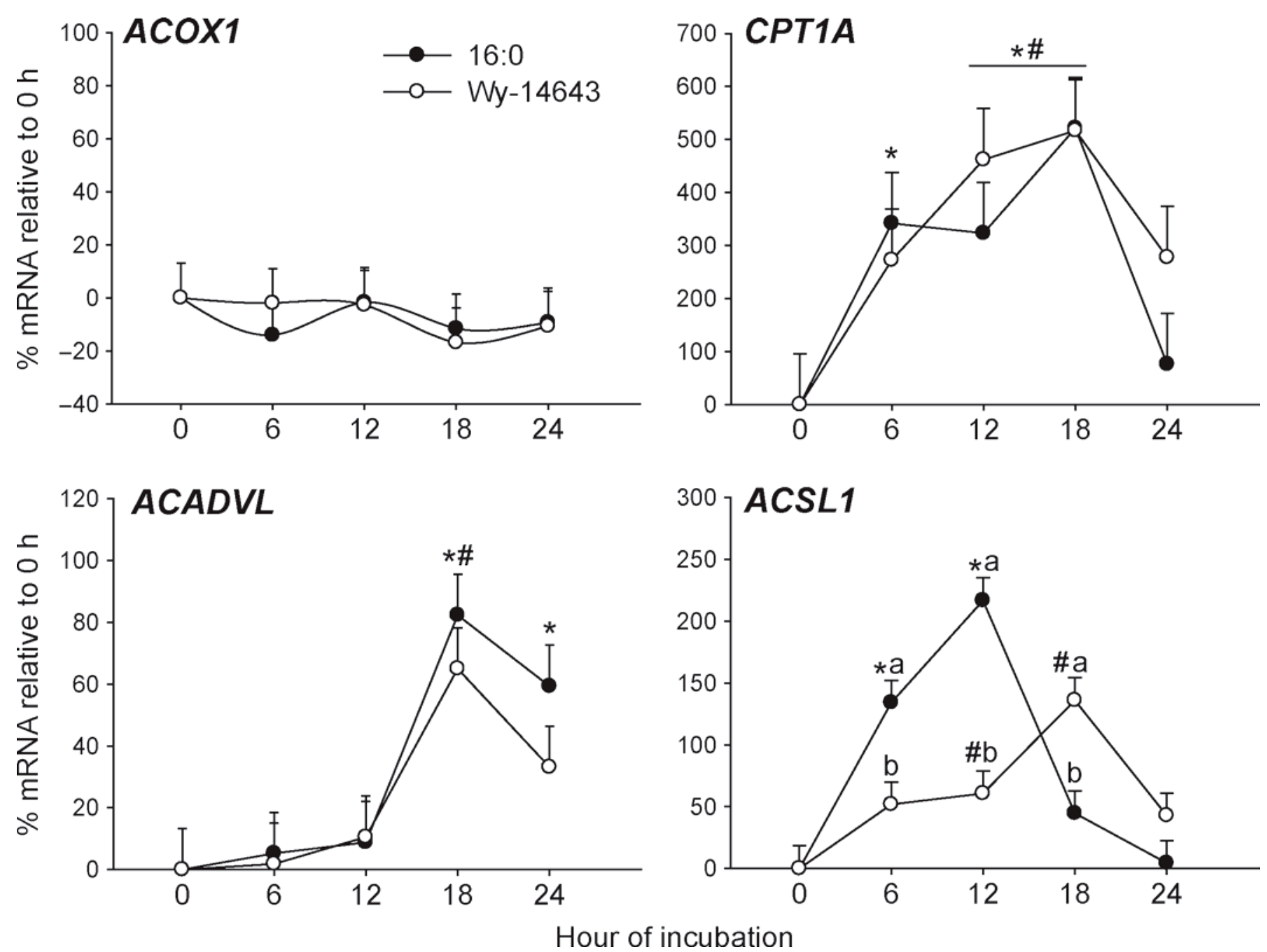

Figure 1. Temporal mRNA expression of putative bovine peroxisome proliferator-activated receptor- $\alpha$ (PPAR $\alpha)$ target genes [acyl- coenzyme A oxidase 1 (ACOX1), carnitine palmitoyl transferase-1A (CPT1A), acyl-coenzyme A dehydrogenase very long chain $(A C A D V L)$, acyl-coenzyme A synthetase long-chain family member 1 (ACSL1)] in response to Wy-14643 (WY) and palmitate (16:0) (experiment 1). The treatment $\times$ time effect was significant $(P<0.05)$ only for acyl-coenzyme A synthetase long-chain family member 1 (ACSL1). The time effect was significant $(P<0.05)$ for all genes except $A C O X 1$. The treatment effect tended to be significant $(P=0.09)$ for $A C S L 1$. The asterisk $(*)$ and pound sign $(\#)$ denote differences $(P<0.05)$ relative to $0 \mathrm{~h}$ for 16:0 and WY. Letters $(\mathrm{a}, \mathrm{b})$ denote differences $(P<0.05)$ between $16: 0$ and WY at specific time points.

With ACSL1, we observed increased expression at $18 \mathrm{~h}$ post-WY treatment. We did not observe a significant difference in potency between WY and 16:0 on the activation of $C P T 1 A$ and $A C A D V L$.

Based on the overall expression pattern of CPT1A and $A C A D V L$, it seems that 16:0 was as effective as WY in activating PPAR $\alpha$. Of note, 16:0 was bound with albumin, which could have affected its overall potency. Large differences in responses among treatments were observed for ACSL1, where 16:0 induced a $340 \%$ increase in expression of this gene as early as $6 \mathrm{~h}$ posttreatment, which lasted through $18 \mathrm{~h}$. In contrast, WY caused an increase in ACSL1 expression by $12 \mathrm{~h}$ posttreatment. These latter findings suggest that 16:0 might activate ACSL1 expression through other transcription factors besides PPAR $\alpha$.

We observed a linear increase in mRNA expression of PPARA in response to $16: 0$ and a numerical temporal linear increase in PPARGC1A expression with WY and 16:0 (Figure 2). A striking effect of 16:0 was observed for LPIN1 expression, which had a very similar pattern to ACSL1. The mechanism of transcription regulation elicited by LPIN1 has not been clearly established (Reue and Zhang, 2008). A recent study demonstrated that glucocorticoids regulate murine LPIN1 expression in vivo (Zhang et al., 2008), but, to our knowledge, 

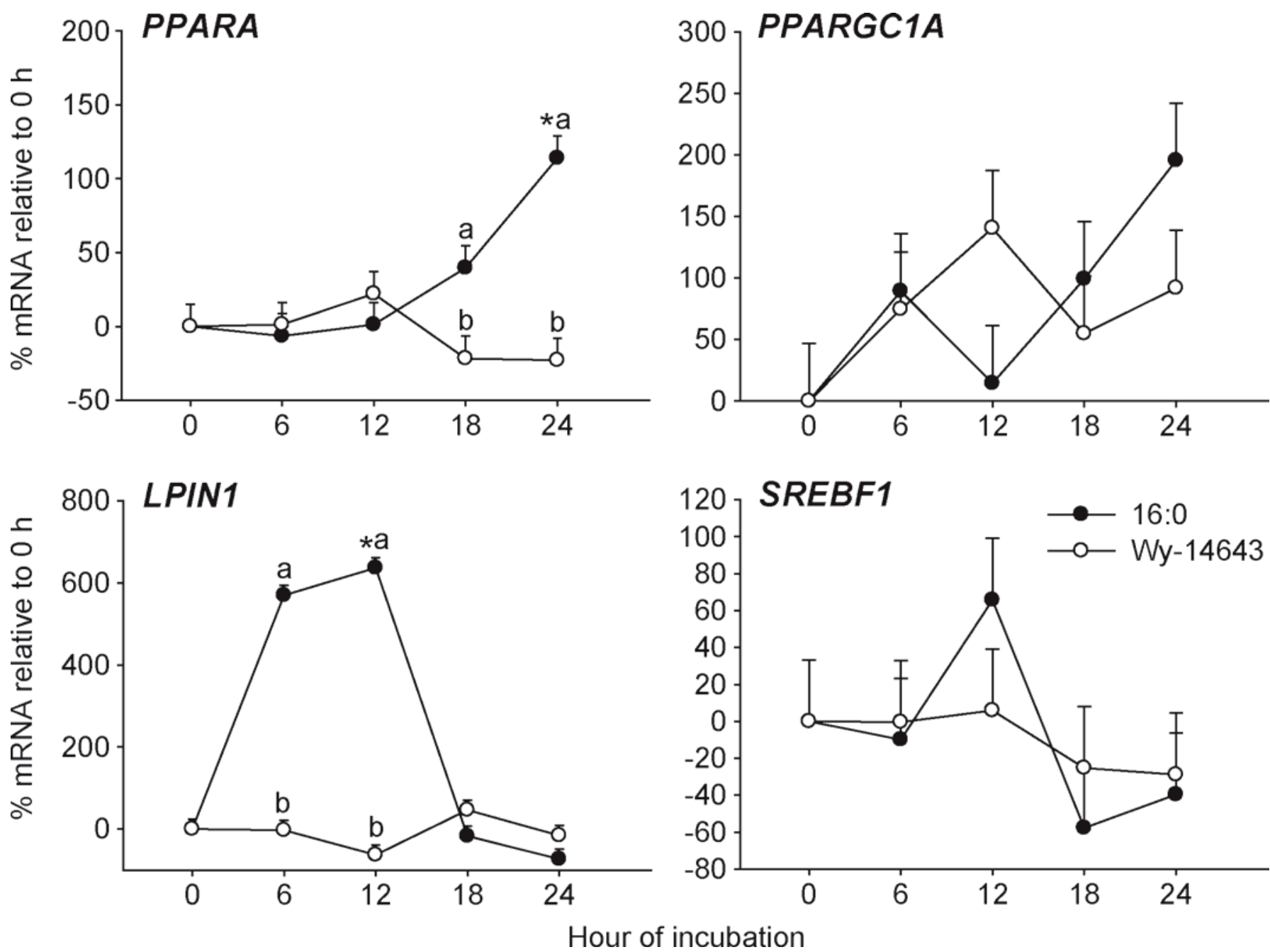

Figure 2. Temporal mRNA expression of peroxisome proliferator-activated receptor- $\alpha$ gene (PPARA), its putative coactivators $[$ peroxisome proliferative-activated receptor- $\gamma$ coactivator $1 \alpha(P P A R G C 1 A)$, lipin 1 (LPIN1)], and the lipogenic transcription factor sterol regulatory element-binding factor 1 (SREBF1) in response to $\mathrm{Wy}-14643(\mathrm{WY})$ and palmitate (16:0; experiment 1). The treatment $\times$ time effect was significant $(P<0.05)$ for PPARA and LPIN1. The time effect was significant $(P<0.05)$ for LPIN1, and a tendency was observed for PPARA $(P=$ $0.06)$. Treatment was significant $(P<0.05)$ for $P P A R A$ and $L P I N 1$. The asterisk $\left(^{*}\right)$ and pound sign $(\#)$ denote differences $(P<0.05)$ relative to $0 \mathrm{~h}$ for 16:0 and WY. Letters $(\mathrm{a}, \mathrm{b})$ denote differences $(P<0.05)$ between 16:0 and WY at specific time points.

there are no reports on the effects of LCFA on LPIN1 expression. Our data strongly suggest that LPIN1 expression is regulated by 16:0 in bovine epithelial cells. It has been demonstrated that lipin 1 is a cofactor required for PPAR $\alpha$ activation in murine liver (Finck et al., 2006). An additional function of LPIN1 in nonruminants is in adipose tissue TG synthesis (Reue and Zhang, 2008), and recent data from our laboratory suggest it also is essential for milk TG synthesis in bovine mammary tissue (Bionaz and Loor, 2008). The precise function(s) of LPIN1 in ruminants require more functional studies, but a possible role of this protein in PPAR $\alpha$ activity and TG synthesis cannot be excluded in these mammals.
The lack of LPIN1 expression in response to WY confirms that this gene is not a PPAR $\alpha$ target, at least in this bovine cell line. Together with ACSL1, the temporal pattern of LPIN1 with 16:0 supports the view that this LCFA could act through other transcription factors besides PPAR $\alpha$ to elicit a metabolic response once it reaches the cell. We envision a situation in which 16:0 first activates one nuclear receptor (or transcription factor), causing activation of a subset of genes, followed by PPAR $\alpha$ activation, causing activation of a different set of genes. The regulation of ACSL1 expression by PPAR $\alpha$ agonists has been uncovered in rat heart treated for $24 \mathrm{~h}$ with WY (Durgan et al., 2006), and we confirmed a similar effect in bovine cells. The 
lipogenic transcription factor $S R E B F 1$ was not affected by WY or 16:0, confirming it is not a PPAR $\alpha$ downstream target in MDBK cells.

\section{Role of Albumin and Insulin on 16:0 Effects}

The use of fatty acid bound to albumin is common practice in cell culture studies, primarily because it closely mimics the in vivo system (Cadorniga-Valino et al., 1997; Mashek and Grummer, 2003). Each molecule of albumin in serum can bind and render up to 6 fatty acids soluble in hydrophilic media (Brodersen et al., 1990). However, albumin can potentially bind more fatty acids. The affinity for the first 2 fatty acids is high; affinity then decreases in a linear fashion with further addition of fatty acids (Brodersen et al., 1990). Those data clearly suggest that the use of albumin in cell culture studies can decrease the availability of FFA for cellular metabolism. Calculations of the true availability of fatty acids using step-wise addition of albumin (Spector, 1975) showed that extremely low amounts of FFA were available to cells (Olofsson et al., 2004). Previous cell culture data highlighted a reduction in availability of fatty acids when albumin was added (DeGrella and Light, 1980; Ranheim et al., 1994). An additional complicating factor is the fact that the affinity of albumin varies among fatty acids (Spector, 1975).

With the above in mind, it was apparent that the use of albumin could limit the availability of LCFA for cells and thus become a confounding factor in experiments in which multiple fatty acids with different chain lengths and saturations are used. In addition, during in vitro treatment of cells with LCFA for 24 to $48 \mathrm{~h}$, the amount of fatty acids taken up by the cells (i.e., released by albumin) is not replenished. This condition ultimately leads to a potential increase in the binding affinity of albumin, reducing the availability of the remaining fatty acids to cells. Thus, a direct evaluation of coupling albumin to fatty acids on gene expression was necessary. Results from this experiment are shown in Figure 3. Data generated from $+\mathrm{Alb} /-\mathrm{Ins}$ can be compared with experiment 1 because, in that experiment, 16:0 was coupled with albumin and no insulin was added to culture medium. This comparison also is important to check the consistency of the response of cells in replicated experiments. As illustrated by responses obtained for CPT1A, ACSL1, and LPIN1, it was apparent that the response of MDBK cells was consistent.

The use of albumin clearly reduced the effect of 16:0 on LPIN1 and ACSL1 expression, which had a lower or delayed peak, or both, and absence of a rebound at 24 $\mathrm{h}$ as compared with the treatment with free 16:0 (i.e., not bound with albumin; Figure 3). The response of the 2 PPAR $\alpha$ target genes was more pronounced with free 16:0 only after $18 \mathrm{~h}$ of treatment. Overall, the data suggest that the use of albumin for the most part dampened the effect of 16:0 in inducing mRNA expression changes across all genes tested. However, the extent of this response could vary among genes. For example, use of albumin should be avoided if the specific genes of interest are ACSL1 and LPIN1. The same might be the case in studies encompassing $>18$-h incubations of $16: 0$ and in which expression of PPAR $\alpha$ target genes such as $C P T 1 A$ and $A C A D V L$ are of specific interest.

In experiment 2 , we did not measure the proliferation or viability of the cells with Trypan blue to assess potential toxic effects of free 16:0. A toxic effect of 16:0 has been observed previously (Bionaz et al., 2008a), and also in a separate experiment from our laboratory dealing with multiple LCFA at 100 or $200 \mu M$ bound 1:4 to albumin (B. Thering, M. Bionaz, and J. Loor, unpublished data). In the latter, $200 \mu M$ albuminbound 16:0 was detrimental to cell viability. Instead of using cell viability to assess potential toxic effects of 16:0, we recorded percentage of cell confluence in all flasks during the entire time course. Those data clearly showed an equal increase in confluence across all treatments between $0(\sim 70 \%)$ and $12 \mathrm{~h}(\sim 80 \%)$, but a substantial decrease at $18(-50 \%)$ and $24(-25 \%)$ $\mathrm{h}$ with $150 \mu M$ free 16:0. In addition, there was a less pronounced but consistent reduction in confluence in cells cultured with $150 \mu M$ free 16:0 plus insulin $(75 \%$ at $18 \mathrm{~h} ; 50 \%$ at $24 \mathrm{~h}$ ). The MDBK cells cultured with $150 \mu M$ albumin-bound 16:0 or ethanol (control) had an increase in confluence $(85 \%$ at $18 \mathrm{~h}$ and $90 \%$ at $24 \mathrm{~h}$ for albumin-bound $16: 0 ;>95 \%$ at $18 \mathrm{~h}$ and $100 \%$ at 24 $\mathrm{h}$ for the control). These data are suggestive of a toxic effect of $150 \mu M$ free 16:0 on MDBK cells. Data also suggest that insulin tends to reduce the toxicity of 16:0. It is noteworthy that detrimental effects were obvious after the 12-h treatment, but we cannot exclude the possibility that cells already were responding before 6 $\mathrm{h}$ of incubation. Despite the toxic effects observed, the data also indicate that through $12 \mathrm{~h}$ posttreatment, cells remained viable.

Insulin is an essential hormone for cell culture because cells use glucose as a primary source of energy (Werner and Noe, 1993). Previously, insulin has been added in media in metabolic studies with calf hepatocyte cultures (Donkin and Armentano, 1993; Cadorniga-Valino et al., 1997; Mashek and Grummer, 2003). In our study, the effect of adding insulin (-Alb/+Ins) on mRNA expression was evident as early as $6 \mathrm{~h}$ posttreatment, when expression of ACSL1 and CPT1A was greater compared with the absence of insulin. It appears from our data that addition of insulin might increase the re- 

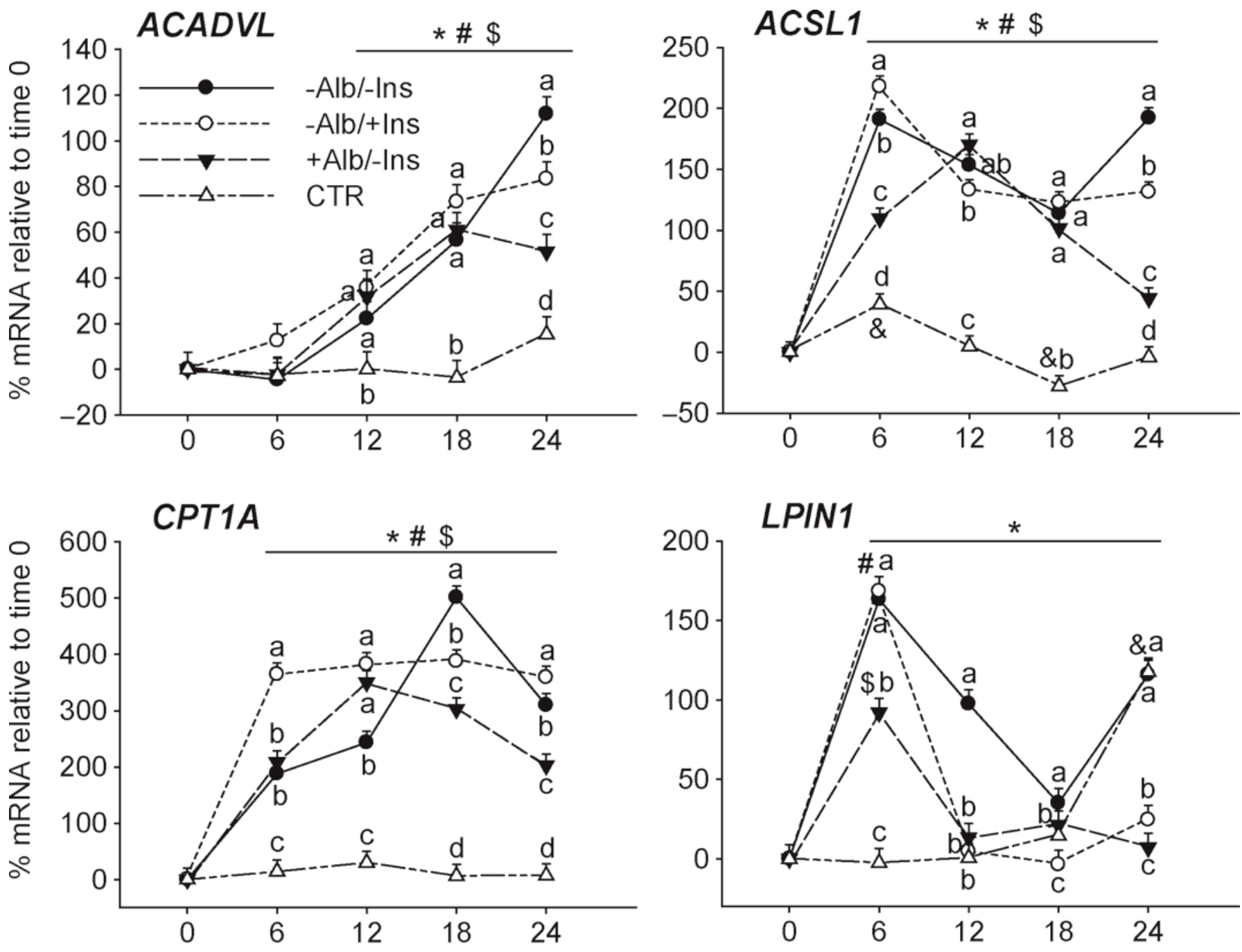

Hour of incubation

Figure 3. Temporal response of putative bovine peroxisome proliferator-activated receptor- $\alpha$ (PPAR $\alpha)$ target genes acyl-coenzyme A dehydrogenase very long chain $(A C A D V L)$, acyl-coenzyme A synthetase long-chain family member 1 (ACSL1), carnitine palmitoyl transferase-1A (CPT1A) and a potential coactivator (lipin 1, LPIN1) in response to palmitate (16:0) without albumin or insulin (-Alb/-Ins), 16:0 without albumin plus $5 \mathrm{mg} / \mathrm{L}$ of bovine insulin $(-\mathrm{Alb} /+\mathrm{Ins}), 16: 0$ with albumin and without insulin $(+\mathrm{Alb} /-$ Ins), or ethanol (control; experiment 2). The treatment $\times$ time interaction was significant $(P<0.01)$ for all genes. The effect of coupling 16:0 with albumin was significant $(P<0.05)$ for all genes and tended $(P=0.08)$ to be significant for $A C A D V L$. The overall effect of insulin was significant $(P<0.05)$ for $C P T 1 A$ and $L P I N 1$. There was a significant overall $(P<0.05)$ treatment and time effects on the expression of all genes. The asterisk $(*)$, pound sign $(\#)$,dollar sign $(\$)$, and ampersand $(\&)$ denote differences $(P<0.05)$ relative to $0 \mathrm{~h}$ for 16:0 without albumin or insulin $(-\mathrm{Alb} /-\mathrm{Ins})$, 16:0 without albumin plus $5 \mathrm{mg} / \mathrm{L}$ of bovine insulin (-Alb/ $+\mathrm{Ins}), 16: 0$ with albumin and without insulin (+Alb/-Ins), and ethanol (control), respectively. Letters (a-d) denote differences $(P<0.05)$ between treatments at a specific time point.

sponse of LCFA-regulated PPAR $\alpha$ target or nontarget genes, particularly in short-term studies (i.e., $<12 \mathrm{~h}$ ) using MDBK cells.

\section{Metabolic Adaptation, Cell Proliferation, and Lipid Accumulation of MDBK Cells Cultured with 16:0}

The measurement of metabolic variables in surfactant media (Figure 4) provided useful information regarding the metabolic adaptations of MDBK cells under normal culture conditions (i.e., control) and after treatment with 16:0. In addition, the expression of selected genes in experiments 1 and 2 is suggestive of large uptake and utilization of the LCFA by cells. The LCFA taken up can be oxidized or used for synthesis of lipids such as TG. Medium from MDBK cells with the control had a temporal increase in urea and TG, with a concomitant decrease in glucose and no change in total protein. Those data are indicative of substantial utilization of AA and glucose as energy sources. There also was evi- 
Urea $(\mathrm{mg} / \mathrm{dL})$

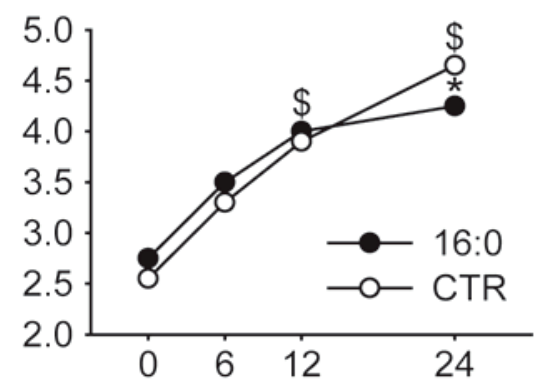

$\operatorname{NEFA}(\mathrm{mEq} / \mathrm{L})$

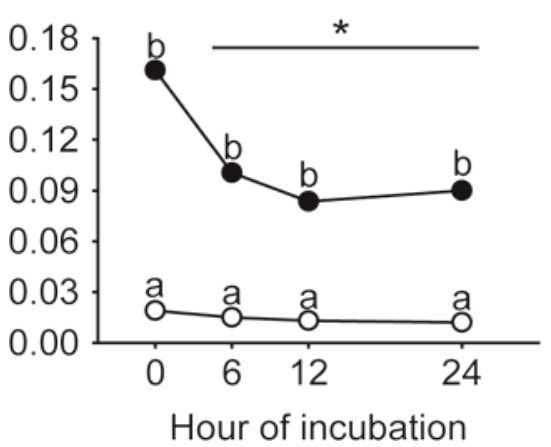

Total Protein (g/dL)

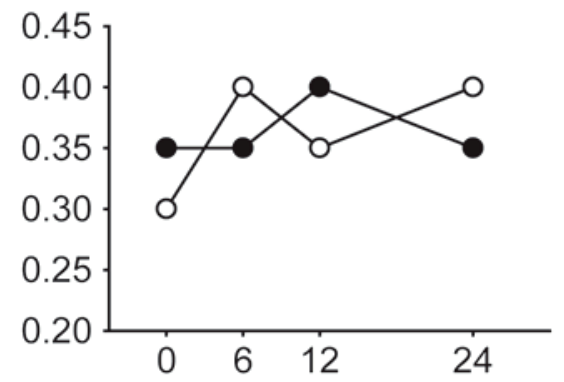

TAG (mg/dL)

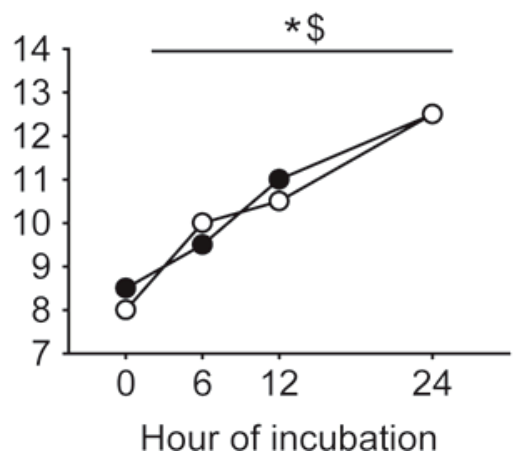

Glucose (mg/dL)

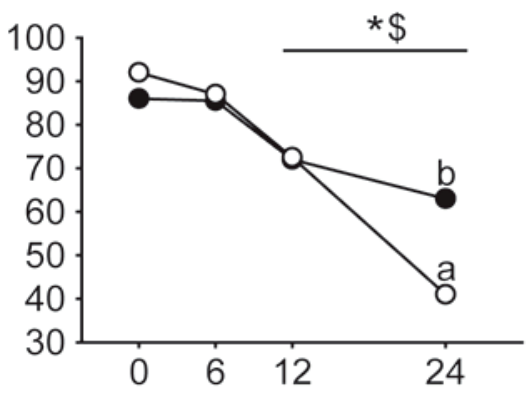

\# cells $\left(\times 10^{5}\right)$ and $\%$ confluence

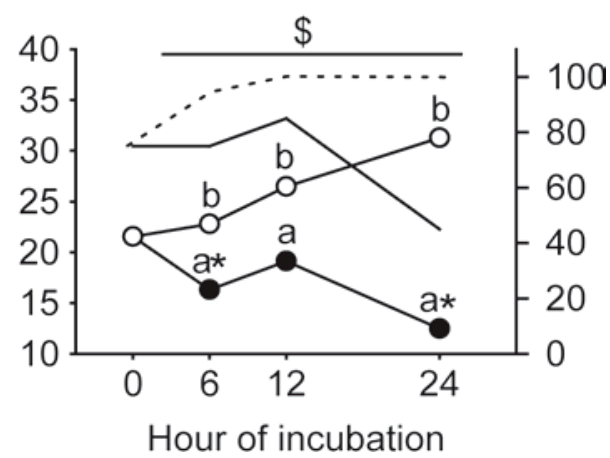

Figure 4. Temporal measurements of selected metabolites in surfactant media, number of cells, and percentage of confluence from MadinDarby bovine kidney (MDBK) cells treated with palmitate (16:0) or ethanol (control). Percentage of confluence is reported by a full line for 16:0 and a dashed line for the control. Time was significant $(P<0.05)$ for all variables except total protein and number of cells. Treatment was significant only for NEFA, number of cells, and percentage of confluence. The time $\times$ treatment interaction was significant for NEFA, number of cells, and percentage of confluence, with a tendency $(P=0.08)$ for glucose concentration. The asterisk $(*)$ and pound sign $(\#)$ denote differences $(P<0.05)$ in each time point relative to $0 \mathrm{~h}$ for 16:0 and the control. Letters $(\mathrm{a}, \mathrm{b})$ denote differences $(P<0.05)$ between treatments at specific time points. Symbols denoting significant differences for percentage of confluence are not included in the graph. TAG $=$ triacylglycerol.

dence of continuous secretion of TG into the medium. Cells were cultured in essential medium with $10 \%$ fetal bovine serum, which resulted in approximately 0.019 $\mathrm{mEq} / \mathrm{L}$ of estimated total NEFA. At $24 \mathrm{~h}$ of incubation, cells had a low estimated uptake of NEFA (i.e., 0.007 $\mathrm{mEq} / \mathrm{L})$. This amount was not enough to explain the increase of TG in medium over time $(+4.5 \mathrm{mg} / \mathrm{dL}$ at 24 $\mathrm{h}$, which corresponded to $0.05 \mathrm{mmol} / \mathrm{L}$ of LCFA). Together, data suggest that MDBK cells were producing fatty acids de novo, likely using glucose as a $\mathrm{C}$ source. Coupled with Oil-O-Red staining (supplementary online-only figure; http://jds.fass.org/content/vol92/ issue5), which did not show any accumulation of lipid droplets in the control, it appeared that most, if not all, the TG produced was secreted and not stored in the cell. The biological meaning of this apparent secretion of TG is not evident.

Cells treated with 16:0, compared with the control, had a similar temporal response in all metabolic variables, except for glucose, which tended to remain higher in medium at $24 \mathrm{~h}$ posttreatment. The dynamics of NEFA uptake also were similar to the control, although with a difference in magnitude. In fact, during the first 6 $\mathrm{h}$ of incubation, the rate at which cells took up 16:0 was $10.1 \pm 0.2 \mathrm{mEq} /(\mathrm{L} \times \mathrm{h})$, followed by a minor decrease from 6 to $12 \mathrm{~h}[2.8 \pm 0.2 \mathrm{mEq} /(\mathrm{L} \times \mathrm{h})]$, and null uptake afterward. Those cells also had a slight accumulation of TG at $24 \mathrm{~h}$ (supplementary online-only figure; http:// jds.fass.org/content/vol92/issue5). It was striking that the accumulation appeared at $24 \mathrm{~h}$, in parallel with the decrease in expression of CPT1A in experiments 1 and 2. Overall, our data indicate that MDBK cells cultured with 16:0 relied heavily on fatty acids as energy sources during the first $18 \mathrm{~h}$ (likely through mitochondrial fatty acid oxidation), which probably explains the apparent reduction in utilization of glucose compared with the control. Subsequently, when CPT1A decreased in expression or activity, the LCFA were utilized for TG synthesis, leading to the formation of lipid droplets. It could be possible that 16:0 also increased expression of lipogenic genes in MDBK cells, as observed in our laboratory using immortalized bovine mammary epithelial cells cultured with this LCFA (Kadegowda et al., 2008). 
In experiment 3 , we evaluated the proliferation of MDBK cells cultured with $150 \mu M$ free 16:0 (Figure 4). The data clearly indicated a significant decrease in cell proliferation already by $6 \mathrm{~h}$ of treatment and a large decrease in the number of adherent cells by 24 $\mathrm{h}$ of treatment. We did not measure the viability of detached cells because the method of harvesting (i.e., trypsin after elimination of surfactant media) eliminates all these cells, which are presumably dead. However, those harvested cells had $>99 \%$ viability as measured by Trypan blue. A decrease in the number of cells also was apparent by a simple assessment of percentage of confluence (Figure 4). Negative effects on cell proliferation also have been observed in our laboratory with 150 $\mu M$ free trans-10, cis-12 18:2 (B. Thering, M. Bionaz, and J. Loor, unpublished data). Further, the effect was larger than that of free 16:0.

\section{Preliminary Evaluation of PPARa Activity}

Genes are under the control of multiple transcription factors, some of which are able to bind LCFA (Desvergne et al., 2006). Thus, in the present study it is possible that increased expression of the selected genes after LCFA treatment was elicited by other transcription factors besides PPARa. Clearly, our approach to assess PPAR $\alpha$ activity was indirect (i.e., relying solely on mRNA expression). A direct measurement of PPAR $\alpha$ activity is deemed necessary to complement mRNA analysis. We tested the PPAR $\alpha, \operatorname{PPAR} \delta$, and PPAR $\gamma$ Complete Transcription Factor Assay Kits from Cayman Chemical (no. 10008878, Cayman Chemical, Ann Arbor, MI), which has been developed for the human and mouse, but (to our knowledge) has not been tested for the bovine. The kit measures the amount of activated PPAR isoforms via direct interaction with peroxisome proliferator response element coated in a 96-well plate by means of a specific PPAR $\alpha$ polyclonal antibody. To test this kit, we cultured MDBK cells with $150 \mu M$ WY, 16:0 (in ethanol without albumin), and ethanol (control) for $4.5 \mathrm{~h}$. After incubation, we performed nuclear extraction by using a Nuclear Extraction Kit (no. 10009277, Cayman Chemical). Results for 16:0, WY, and the control on PPAR $\alpha$ activity are reported in Figure 5. The 16:0 treatment resulted in greater PPAR $\alpha$ activity compared with other treatments (e.g., +1.2 -fold vs. control, $P=0.02$ ). Intuitively, small changes in activity of nuclear receptors should accompany larger responses in mRNA of target genes and potentially protein. This appeared to be the case when comparing results of PPAR $\alpha$ activity vs. mRNA of CPT1A in the response to 16:0 (Figure 1 and 2), which resulted in approximately $500 \%$ increase in mRNA expression after $6 \mathrm{~h}$. The same conclusion cannot be made

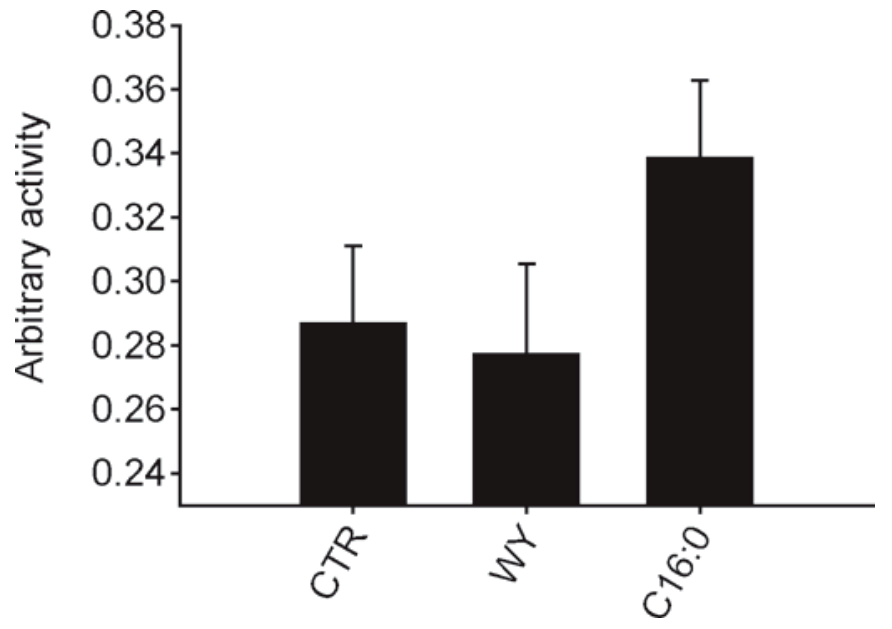

Figure 5. Peroxisome proliferator-activated receptor- $\alpha$ (PPAR $\alpha)$ activity measured by the PPAR Complete Transcription Factor Assay Kit (Cayman Chemical, Ann Arbor, MI) in Madin-Darby bovine kidney (MDBK) cells after treatment with $150 \mu M \mathrm{Wy}-14643$ (WY), palmitate (16:0), and ethanol (control; CTR). The overall treatment effect had a $P=0.17$, and $16: 0$ had a $P<0.03$ ( $t$-test) compared with both WY and the control.

in the case of WY, which led to a similar increase in expression of CPT1A as 16:0 without greater PPAR $\alpha$ activity. Clearly, more studies are necessary to evaluate the feasibility of using this kit to measure bovine PPAR activity.

\section{CONCLUSIONS}

Overall, the data highlighted the complexity of responses to LCFA by MDBK cells. A thorough discussion, however, was beyond the scope of this paper. The series of experiments confirmed that MDBK are responsive to LCFA and the PPAR $\alpha$ agonist WY, as previously observed (Bionaz et al., 2008a). The ACOX1 did not appear to be a PPAR $\alpha$ target gene in this bovine cell line. Experiments also uncovered novel responses of ACSL1 and LPIN1 to 16:0, suggesting that this LCFA affects gene transcription through other transcription factors besides PPAR . In addition, $150 \mu \mathrm{M}$ albumin-bound 16:0 or WY did not impair the viability and proliferation of cells. However, $150 \mu M$ free 16:0 already had a negative effect on cell proliferation by $6 \mathrm{~h}$, and the effect was detrimental after 12 $\mathrm{h}$ of incubation. Despite potential toxic effects during long-term incubations, free LCFA in ethanol (i.e., not bound to albumin) plus addition of insulin for $\leq 12$ $\mathrm{h}$ seems to increase the response of MDBK cells. We propose, based on expression of CPT1A, LPIN1, and $A C S L 1$, and cell proliferation data, that $6 \mathrm{~h}$ of incubation of MDBK cells is a suitable compromise to study the effects of moderately high doses (i.e., $150 \mu M$ ) of free LCFA on PPAR $\alpha$ activation. Lower doses of LCFA 
might be more suitable for longer term experiments. Retrospectively, it is apparent that the use of cells with a low number of passages would probably yield the most biologically relevant information.

\section{ACKNOWLEDGMENTS}

Support for this work was provided by USDA-Cooperative State Research, Education, and Extension Service Section 1433 Animal Health and Disease Funds appropriated to the Illinois Agricultural Experiment Station under award numbers 5380-952 and 538-961 (to JJL).

\section{REFERENCES}

Andersen, J. B., C. Ridder, and T. Larsen. 2008. Priming the cow for mobilization in the periparturient period: Effects of supplementing the dry cow with saturated fat or linseed. J. Dairy Sci. 91:10291043.

Bionaz, M., C. R. Baumrucker, E. Shirk, J. P. Vanden Heuvel, E. Block, and G. A. Varga. 2008a. Characterization of madin-darby bovine kidney cell line for peroxisome proliferator-activated receptors: Temporal response and sensitivity to fatty acids. J. Dairy Sci. 91:2808-2813.

Bionaz, M., R. E. Everts, H. A. Lewin, J. K. Drackley, and J. J. Loor. 2008b. Bovine kidney (MDBK) cells and liver tissue of periparturient cows share remarkable similarity in gene expression profiles. J. Dairy Sci. 91(Suppl. 1):178. (Abstr.)

Bionaz, M., and J. J. Loor. 2007. Identification of reference genes for quantitative real-time PCR in the bovine mammary gland during the lactation cycle. Physiol. Genomics 29:312-319.

Bionaz, M., and J. J. Loor. 2008. Gene networks driving bovine milk fat synthesis during the lactation cycle. BMC Genomics 9:366.

Brodersen, R., S. Andersen, H. Vorum, S. U. Nielsen, and A. O. Pedersen. 1990. Multiple fatty acid binding to albumin in human blood plasma. Eur. J. Biochem. 189:343-349.

Cadorniga-Valino, C., R. R. Grummer, L. E. Armentano, S. S. Donkin, and S. J. Bertics. 1997. Effects of fatty acids and hormones on fatty acid metabolism and gluconeogenesis in bovine hepatocytes. J. Dairy Sci. 80:646-656.

DeGrella, R. F., and R. J. Light. 1980. Uptake and metabolism of fatty acids by dispersed adult rat heart myocytes. II. Inhibition by albumin and fatty acid homologues, and the effect of temperature and metabolic reagents. J. Biol. Chem. 255:9739-9745.

Desvergne, B., L. Michalik, and W. Wahli. 2006. Transcriptional regulation of metabolism. Physiol. Rev. 86:465-514.

Donkin, S. S., and L. E. Armentano. 1993. Preparation of extended in vitro cultures of bovine hepatocytes that are hormonally responsive. J. Anim. Sci. 71:2218-2227.

Drackley, J. K. 1999. ADSA Foundation Scholar Award. Biology of dairy cows during the transition period: The final frontier? J. Dairy Sci. 82:2259-2273.

Durgan, D. J., J. K. Smith, M. A. Hotze, O. Egbejimi, K. D. Cuthbert, V. G. Zaha, J. R. Dyck, E. D. Abel, and M. E. Young. 2006. Distinct transcriptional regulation of long-chain acyl-CoA synthetase isoforms and cytosolic thioesterase 1 in the rodent heart by fatty acids and insulin. Am. J. Physiol. Heart Circ. Physiol. 290:H2480-H2497.

Finck, B. N., M. C. Gropler, Z. Chen, T. C. Leone, M. A. Croce, T. E. Harris, J. C. Lawrence Jr, and D. P. Kelly. 2006. Lipin 1 is an inducible amplifier of the hepatic PGC-1alpha/PPARalpha regulatory pathway. Cell Metab. 4:199-210.

Harvatine, K. J., and D. E. Bauman. 2006. SREBP1 and thyroid hormone responsive spot 14 (S14) are involved in the regulation of bovine mammary lipid synthesis during diet-induced milk fat depression and treatment with CLA. J. Nutr. 136:2468-2474.

Jump, D. B. 2002. Dietary polyunsaturated fatty acids and regulation of gene transcription. Curr. Opin. Lipidol. 13:155-164.
Kadegowda, A. K. G., M. Bionaz, L. S. Piperova, R. A. Erdman, and J. J. Loor. 2008. Lipogenic gene expression in MAC-T cells is affected differently by fatty acids and enhanced by PPAR-gamma activation. J. Dairy Sci. 91(Suppl. 1):678. (Abstr.)

Kumamoto, T., and T. Ide. 1998. Comparative effects of alpha- and gamma-linolenic acids on rat liver fatty acid oxidation. Lipids 33:647-654.

Lambert, M. S., M. A. Avella, K. M. Botham, and P. A. Mayes. 1998. Comparison of short- and long-term effects of different dietary fats on the hepatic uptake and metabolism of chylomicron remnants in rats. Br. J. Nutr. 79:203-211.

Lehmann, J. M., J. M. Lenhard, B. B. Oliver, G. M. Ringold, and S. A. Kliewer. 1997. Peroxisome proliferator-activated receptors alpha and gamma are activated by indomethacin and other non-steroidal anti-inflammatory drugs. J. Biol. Chem. 272:3406-3410.

Loor, J. J., H. M. Dann, R. E. Everts, R. Oliveira, C. A. Green, N. A. Guretzky, S. L. Rodriguez-Zas, H. A. Lewin, and J. K. Drackley. 2005. Temporal gene expression profiling of liver from periparturient dairy cows reveals complex adaptive mechanisms in hepatic function. Physiol. Genomics 23:217-226.

Loor, J. J., R. E. Everts, M. Bionaz, H. M. Dann, D. E. Morin, R. Oliveira, S. L. Rodriguez-Zas, J. K. Drackley, and H. A. Lewin. 2007. Nutrition-induced ketosis alters metabolic and signaling gene networks in liver of periparturient dairy cows. Physiol. Genomics $32: 105-116$

Malewiak, M. I., R. Rozen, X. Le Liepvre, and S. Griglio. 1988. Oleate metabolism and endogenous triacylglycerol hydrolysis in isolated hepatocytes from rats fed a high-fat diet. Diabet. Metab. 14:270276

Mandard, S., M. Muller, and S. Kersten. 2004. Peroxisome proliferatoractivated receptor alpha target genes. Cell. Mol. Life Sci. 61:393416

Mashek, D. G., and R. R. Grummer. 2003. Effects of long chain fatty acids on lipid and glucose metabolism in monolayer cultures of bovine hepatocytes. J. Dairy Sci. 86:2390-2396.

Mashek, D. G., and R. R. Grummer. 2004. Effects of conjugated linoleic acid isomers on lipid metabolism and gluconeogenesis in monolayer cultures of bovine hepatocytes. J. Dairy Sci. 87:67-72.

Olofsson, C. S., A. Salehi, C. Holm, and P. Rorsman. 2004. Palmitate increases L-type $\mathrm{Ca}^{2+}$ currents and the size of the readily releasable granule pool in mouse pancreatic beta-cells. J. Physiol. 557:935948.

Piantoni, P., M. Bionaz, D. E. Graugnard, K. M. Daniels, R. M. Akers, and J. J. Loor. 2008. Gene expression ratio stability evaluation in prepubertal bovine mammary tissue from calves fed different milk replacers reveals novel internal controls for quantitative polymerase chain reaction. J. Nutr. 138:1158-1164.

Ranheim, T., A. Gedde-Dahl, A. C. Rustan, and C. A. Drevon. 1994 Fatty acid uptake and metabolism in CaCo-2 cells: Eicosapentaenoic acid (20:5n-3) and oleic acid (18:1n-9) presented in association with micelles or albumin. Biochim. Biophys. Acta 1212:295-304.

Reue, K., and P. Zhang. 2008. The lipin protein family: Dual roles in lipid biosynthesis and gene expression. FEBS Lett. 582:90-96.

Rubin, H. 1997. Cell aging in vivo and in vitro. Mech. Ageing Dev. 98:1-35.

Santos, J. E., T. R. Bilby, W. W. Thatcher, C. R. Staples, and F. T. Silvestre. 2008. Long chain fatty acids of diet as factors influencing reproduction in cattle. Reprod. Domest. Anim. 43(Suppl. 2):2330 .

Schoonjans, K., G. Martin, B. Staels, and J. Auwerx. 1997. Peroxisome proliferator-activated receptors, orphans with ligands and functions. Curr. Opin. Lipidol. 8:159-166.

Spector, A. A. 1975. Fatty acid binding to plasma albumin. J. Lipid Res. 16:165-179.

Werner, R. G., and W. Noe. 1993. Mammalian cell cultures. Part I: Characterization, morphology and metabolism. Arzneimittelforschung 43:1134-1139.

Zhang, P., L. O'Loughlin, D. N. Brindley, and K. Reue. 2008. Regulation of lipin-1 gene expression by glucocorticoids during adipogenesis. J. Lipid Res. 49:1519-1528. 